\title{
Dehydration of infrared ginger slices: Heat and mass Transfer coefficient and modeling
}

\section{Desidratação de fatias de gengibre por infravermelho: Coeficiente de transferência de calor e massa e modelagem}

\author{
Paulo Cesar Corrêa ${ }^{1}$ D, Fernanda Machado Baptestini' ${ }^{(D)}$, Juliana Soares Zeymer ${ }^{1}$ (D), \\ Marcos Eduardo Viana de Araujo ${ }^{1 *}(\mathbb{D})$, Rita Cristina Pereira de Freitas ${ }^{1}$ (D), Rildo Araujo Leite ${ }^{3}$ (D)
}

\author{
1Universidade Federal de Viçosa/UFV, Departamento de Engenharia Agrícola, Viçosa, MG, Brasil \\ 2Universidade Federal do Espirito Santo/UFES, Departamento de Engenharia Rural, Alegre, ES, Brasil \\ ${ }^{3}$ Instituto Federal do Norte de Minas Gerais/IFNMG, Arinos, MG, Brasil \\ *Corresponding author: marcos.rav@hotmail.com \\ Received in October 30, 2018 and approved in December 12, 2018
}

\begin{abstract}
Dehydration of plant products extends its shelf life and reduces its mass and volume, which increases transport and storage efficiency and adds value to food. However, it is an intensive process in energy and time, making necessary the search for more efficient technologies, Thus, this study aimed to investigate the infrared ginger dehydration process by approaching the constant period of dehydration to the theory of mass and heat transfer process to the wet bulb thermometer and the decreasing period of dehydration to liquid diffusion theory. We submitted $5.0 \mathrm{~mm}$ thickness and $2.0 \mathrm{~cm}$ diameter slices to a dryer with infrared radiation at $50,60,70,80,90$ and $100{ }^{\circ} \mathrm{C}$ until constant mass. Heat and mass transfer coefficients, and effective diffusion coefficient increased linearly with temperature increasing, resulting in values ranging from 69.40 to $92.23 \mathrm{~W} \mathrm{~m}^{-2}{ }^{\circ} \mathrm{C}^{-1}, 0.062$ to $0.089 \mathrm{~m} \mathrm{~s}^{-1}$ and $3.81 \times 10^{-9}$ to $1.13 \times 10^{-8} \mathrm{~m}^{2} \mathrm{~s}^{-1}$. Variation of heat and mass transfer coefficients was described by a linear model and the variation of effective diffusion coefficient with the temperature was described with the Arrhenius relation, whose activation energy was $22.07 \mathrm{~kJ} \mathrm{~mol}^{-1}$. The modified Henderson and Pabis model was able to satisfactorily describe the period of decreasing drying rate.
\end{abstract}

Index terms: Modified Henderson and Pabis; radiation; water content; Zingiber officinale.

\begin{abstract}
RESUMO
A desidratação de produtos vegetais prolonga sua vida útil e reduz sua massa e volume, o que aumenta a eficiência de transporte e armazenamento e agrega valor aos alimentos. No entanto, é um processo intensivo em energia e tempo, tornando necessária a busca por tecnologias mais eficientes. Diante do exposto, objetivou-se investigar o processo de desidratação de gengibre por infravermelho através da aproximação do período constante de desidratação à teoria do processo de transferência de calor e de massa para o termômetro de bulbo molhado, e do período decrescente de desidratação à teoria de difusão liquida. Foram utilizadas fatias de 5,0 mm de espessura e $2,0 \mathrm{~cm}$ de diâmetro para serem secas em um secador com fonte de irradiação infravermelha nas temperaturas de $50,60,70,80,90$ e $100^{\circ} \mathrm{C}$, até massa constante. Os coeficientes de transferência de calor e de massa, e o coeficiente de difusão efetivo, aumentaram linearmente com o aumento da temperatura, obtendo-se valores que variaram respectivamente de 69,40 a $92,23 \mathrm{~W} \mathrm{~m}^{-2}{ }^{\circ} \mathrm{C}^{-1}, 0,062$ a $0,089 \mathrm{~m} \mathrm{~s}^{-1}$ e 3,81 $\times 10^{-9}$ a $1,13 \times 10^{-8} \mathrm{~m}^{2} \mathrm{~s}^{-1}$. A variação dos coeficientes de transferência de calor e de massa foi descrita por um modelo linear e a variação do coeficiente de difusão efetivo com a temperatura foi descrita por meio da relação de Arrhenius, cuja energia de ativação foi de 22,07 kJ mol-1. O modelo de Henderson e Pabis modificado foi capaz de descrever satisfatoriamente o período de taxa de secagem decrescente.
\end{abstract}

Termos para indexação: Henderson e Pabis modificado; radiação; teor de água; Zingiber officinale.

\section{INTRODUCTION}

Ginger, obtained from the rhizomes of Zingiber officinale, is one of the most appreciated spices in the world, with attractive odor and spicy taste (Arablou; Aryaeian, 2017; Yu et al., 2017). In addition to using it as a spice, ginger is also a medicinal compound for having several pharmacological features, among which antiinflammatory, antidiabetic, antioxidant, cardiovascular and anticancer activities (Gabr; Alghadir; Ghoniem, 2017; Pattnaik et al., 2016; Rahmani; Shabrmi; Alym, 2014).

Despite being found in natura (unprocessed), most ginger is marketed as post-concentrate and dry products (Jelled et al., 2015). Moisture content reduction 
of agricultural products inherent in the drying process relates to growth inhibition of microorganisms and prevention of biochemical modifications, causing many of the deterioration reactions to be avoided by humidity removal through the drying method (Deshmukh et al., 2014; Phoungchandang; Saentaweesuk, 2011; Pinela et al., 2011).

In addition, dehydration of plant products prolongs its shelf life and reduces mass and volume, which increases transport and storage efficiency and adds value to food (Baptestini et al., 2016), since these products, when they lose water, changes their organoleptic properties, such as aroma, texture, taste and color, increasing consumer interest (Dehghannya; Hosseinlar; Heshmati, 2018).

Drying of food is a very intensive process in energy and time, making it necessary to search for more efficient technologies (Ozdemir et al., 2017). Infrared dehydration offers many advantages over other drying methods (Adak; Heybeli; Ertekin, 2017), in which the radiation energy is transferred from the heating element to the product, heating the material faster and uniform without heating the circulating air (Ozdemir et al., 2017), reducing drying processes up to $50 \%$ (Nowak; Lewicki, 2004).

Drying of wet products is a complex process involving heating and mass transfer (Younis; Abdelkarim; El-Abdein, 2018). Moisture content can move inside a material submitted to drying by different mechanisms (Corrêa et al., 2012). In agricultural products, generally, porous hygroscopic, the possible transport mechanisms of moisture content are liquid diffusion, capillary diffusion, surface diffusion, vapor diffusion, thermal diffusion and hydrodynamic flow (Brooker; Bakker-Arkema; Hall, 1992).

In recent years, some studies have been conducted in the investigation of ginger drying behavior, using different methods and drying systems (Jayashree;
Visvanthan, 2013; Afolabi; Tunde-Akintude; Oyelade, 2014; Parlak, 2015). Specifically for infrared radiation, An et al. (2016) evaluated the influence of this drying method on the chemical characteristics, antioxidant properties and microstructure of ginger slices. Kate and Sutar (2018) evaluated the use of this technology for the peeling of ginger rhizomes as a way to reduce water use and effluent disposal in this process. However, studies on the heat and mass transfer coefficients in infrared drying of ginger slices have not been reported.

This study aimed to determine heat transfer coefficient and process mass, to obtain and model the drying curves and to determine the diffusion coefficient and activation energy of infrared drying of ginger slices in the temperature range of 50 to $100^{\circ} \mathrm{C}$.

\section{MATERIAL AND METHODS}

This study took place at the Laboratory of Physical Properties and Quality Assessment belonging to the National Storage Training Center (CENTREINAR), located on the campus of the Federal University of Viçosa (UFV), Viçosa - Minas Gerais (MG).

Ginger roots (Zingiber officinale) from a farm in the municipality of Viçosa-MG were stored in BOD chambers at $20 \pm 1{ }^{\circ} \mathrm{C}$ during the experiment. Ginger slices with mean initial moisture content of $5.548 \mathrm{~kg}_{\mathrm{a}} \mathrm{kg}_{\mathrm{dm}}{ }^{-1}$ were cut with approximately $0.5 \mathrm{~cm}$ thick and $2.0 \mathrm{~cm}$ diameter. The measurements were made using a Mitutoyo digital pachymeter. Ginger slices were dried in infrared drying equipment (Figure 1 and 2), which provides the initial moisture content and water loss over the drying time. The uncertainties of the measurement instruments was calculated and shown in Table 1.
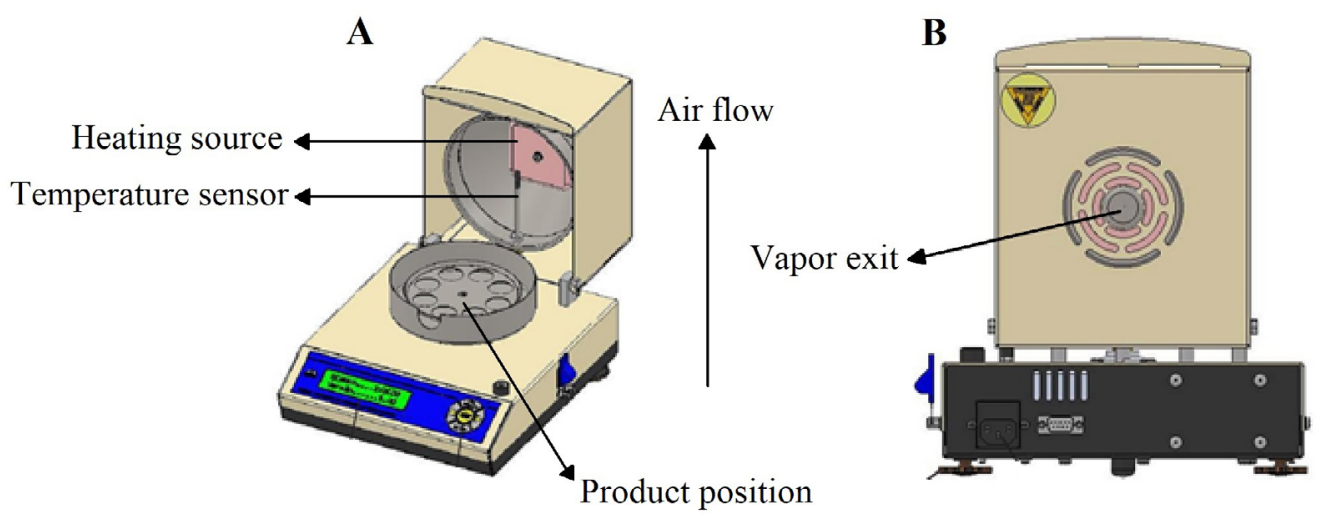

Figure 1: Schematic drawing of the infrared drying equipment, front view (A) and rear view (B) when drying chamber is open.

Source: Adapted from Gehaka (2011). 

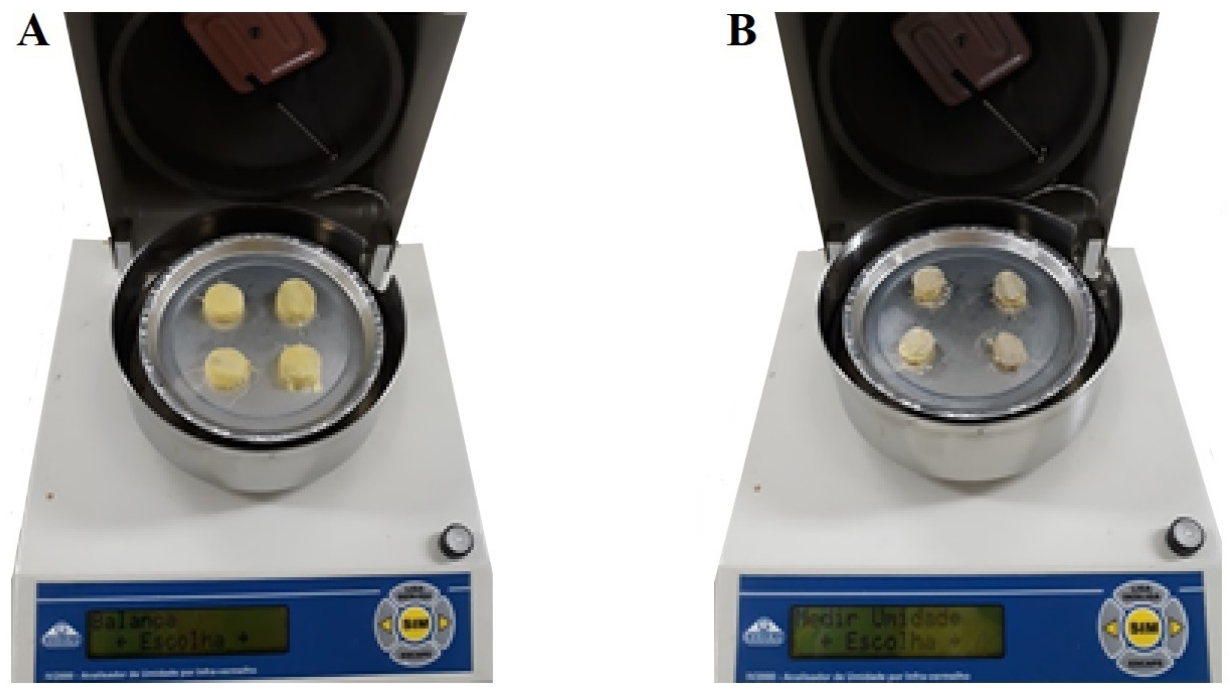

Figure 2: Ginger slices before (A) and after (B) of drying infrared process.

A drier with infrared radiation source (model IV 2500, Gehaka, São Paulo, Brazil) dried the ginger slices at $50,60,70,80,90$ and $100^{\circ} \mathrm{C}$. This equipment contains 0.001 $\mathrm{g}$ precision scale and an automatic data acquisition system, which provides mass variation reading in 1 minute intervals. The equilibrium moisture content occurred when the variation of three consecutive readings was less than $0.01 \mathrm{~g}$.

Table 1: Uncertainties of the measurement instruments used in the experiments.

\begin{tabular}{cc}
\hline Instruments & $\begin{array}{c}\text { Uncertainty instrument } \\
\text { (standard deviation) }\end{array}$ \\
\hline Dryer model IV 2500 scale & $0.423 \mathrm{~g}$ \\
Pachymeter & $0.025 \mathrm{~mm}$ \\
\hline
\end{tabular}

Theories governing the study of constant drying period of agricultural products with high initial moisture contents may approximate to theories of heat and mass transfer balances for the wet bulb thermometer of a psychrometer. Thus, Equation 1 may represent the constant drying rate (Brooker; Bakker-Arkema; Hall, 1992).

$$
\frac{\mathrm{dM}}{\mathrm{dt}}=\frac{\mathrm{h}_{\mathrm{c}} \mathrm{A}}{\mathrm{h}_{\mathrm{fg}}}\left(\mathrm{T}_{\infty}-\mathrm{T}_{\mathrm{bu}}\right)=\frac{\mathrm{h}_{\mathrm{m}} \mathrm{A}}{\mathrm{R}_{\mathrm{V}}}\left(\frac{\mathrm{P}_{\mathrm{vbu}}}{\mathrm{T}_{\mathrm{bu}}}-\frac{\mathrm{P}_{\mathrm{v} \infty}}{\mathrm{T} \infty}\right)
$$

Where $h_{c}$ - global coefficient of heat transfer $\left(\mathrm{W} \mathrm{m}^{-2}\right.$ $\left.{ }^{\circ} \mathrm{C}^{-1}\right), \mathrm{h}_{\mathrm{m}}$ - global coefficient of mass transfer $\left(\mathrm{m} \mathrm{s}^{-1}\right)$, $\mathrm{h}_{\mathrm{fg}}$ - latent heat of vaporization $\left(\mathrm{J} \mathrm{kg}^{-1}\right), \mathrm{R}_{\mathrm{v}}$ - universal constant for water vapor $\left(0.462 \mathrm{~J} \mathrm{~kg}^{-1} \mathrm{~K}^{-1}\right), \mathrm{A}$ - area $\left(\mathrm{m}^{2}\right)$, $\mathrm{P}_{\mathrm{vbu}}$ - vapor pressure for wet bulb temperature $(\mathrm{Pa}), \mathrm{P}_{\mathrm{v} \infty}$ - vapor pressure $(\mathrm{Pa}), \mathrm{T}_{\mathrm{bu}}$ - wet bulb temperature $\left({ }^{\circ} \mathrm{C}\right)$, $\mathrm{T}_{\infty}$ - drying temperature $\left({ }^{\circ} \mathrm{C}\right), \mathrm{dM} / \mathrm{dt}$ - constant drying rate, $\left(\mathrm{kg} \mathrm{s}^{-1}\right)$.

From heat and mass transfer coefficients, we defined the Lewis number, which is relevant for any situation involving the simultaneous transfer of mass and heat by convection using the Equation 2 (Incropera; Dewitt, 2003):

$\frac{h_{c}}{h_{m}}=\rho C_{p} L_{e}^{1-n}=\rho C_{p}\left(\frac{S_{c}}{P_{r}}\right)^{1-n}$

Where $\rho$ - specific air mass $\left(\mathrm{kg} \mathrm{m}^{-3}\right), \mathrm{C}_{\mathrm{p}}$ - specific air heat $(\mathrm{J}$ $\left.\mathrm{kg}^{-1}{ }^{\circ} \mathrm{C}^{-1}\right), \mathrm{L}_{\mathrm{e}}$ - Lewis number (adm.), Sc - Schmidt number (adm.), Pr - Prandtl number (adm.).

This ratio can be used in both turbulent and laminar flow, and for most applications it is reasonable to assume a value of $n=1 / 3$. In order to obtain specific air mass values for each drying air temperature and corrected for height, we used software GRAPSI ${ }^{\circledR}$.

Table 2 shows the adjusted mathematical models traditionally used to describe the drying kinetics of agricultural products to the experimental data of ginger slices drying (in attachment). 
Table 2: Mathematical models used for modeling ginger slice drying.

\begin{tabular}{ccc}
\hline Model denomination & Model \\
\hline Diffusion approach & $\mathrm{MR}=\mathrm{a} \exp (-\mathrm{kt})+(1-\mathrm{a}) \exp (-\mathrm{kbt})$ \\
Exponential of two terms & $\mathrm{MR}=\mathrm{a} \exp (-\mathrm{kt})+(1-\mathrm{a}) \exp (-\mathrm{kat})$ \\
Henderson and Pabis modified & $\mathrm{MR}=\mathrm{a} \exp (-\mathrm{kt})+\mathrm{bexp}(-\mathrm{gt})+\mathrm{cexp}(-\mathrm{ht})$ \\
Logarithm & $\mathrm{MR}=\mathrm{aexp}(-\mathrm{kt})+\mathrm{b}$
\end{tabular}

t - drying time (min), k - drying constant $\left(\min ^{-1}\right), a, b, c, n$ - coefficients of the models (adm.).

Moisture ratio was determined in agreement to Equation 9. Simplification results from infrared drying in which the samples can dry to constant dry matter $\left(\mathrm{M}_{\mathrm{e}}=0\right)$ (Togrul, 2006). In addition, modeling occurred up to moisture content around $0.1364 \mathrm{~kg}_{\mathrm{a}} \mathrm{kg}_{\mathrm{dm}}{ }^{-1}$ in agreement to Resolution RDC No. 272 of September 22, 2005 from ANVISA (Brasil, 2005).

$$
\mathrm{MR}=\frac{\mathrm{M}_{\mathrm{t}}-\mathrm{M}_{\mathrm{e}}}{\mathrm{M}_{\mathrm{o}}-\mathrm{M}_{\mathrm{e}}} \cong \frac{\mathrm{M}_{\mathrm{t}}}{\mathrm{M}_{0}}
$$

Where $M_{t}$ - moisture content at $t$ time $\left(\mathrm{kg}_{\mathrm{a}} \mathrm{kg}_{\mathrm{ms}}{ }^{-1}\right), \mathrm{M}_{0}$ - initial moisture content $\left(\mathrm{kg}_{\mathrm{a}} \mathrm{kg}_{\mathrm{ms}}{ }^{-1}\right), \mathrm{M}_{\mathrm{e}}$ - equilibrium moisture content $\left(\mathrm{kg}_{\mathrm{a}} \mathrm{kg}_{\mathrm{ms}}{ }^{-1}\right)$.

The adjustment of the mathematical models occurred with non-linear regression with the Gauss-Newton method, using software Statistica $8.0^{\circledR}$ (Statsoft, 2004). When selecting the best model we considered: magnitude of coefficient of determination $\left(\mathrm{R}^{2}\right)$, relative mean error (MRE) (Equation 10), estimated standard deviation (SDE) (Equation 11), and the residual distribution.

$$
\begin{gathered}
\mathrm{MRE}=\frac{100}{n_{\text {obs }}} \sum_{i=1}^{n_{\text {obs }}} \frac{\left|Y_{i}-\hat{Y}_{i}\right|}{Y_{i}} \\
\mathrm{SDE}=\sqrt{\frac{\sum_{i=1}^{n_{o b s}}\left(Y_{i}-\hat{Y}_{i}\right)}{G L R}}
\end{gathered}
$$

Where $Y_{\mathrm{i}}$ - observed values, ${ }_{\mathrm{i}}$ - estimated values, $\mathrm{n}_{\mathrm{obs}}$ - number of observed data, MRE - degree of freedom of the residue.
The effective diffusion coefficient was obtained by fitting the mathematical model of liquid diffusion to the experimental data, described by Equation 12. This equation is the analytical solution of Fick's second law, considering the geometric shape of the plate, conditions of moisture content of product surface, without considering the volumetric shrinkage of the product (Afzal; Abe, 1998; Baptestini et al., 2017).

$$
\mathrm{MR}=\frac{8}{\pi^{2}} \sum_{\mathrm{i}=1}^{\mathrm{n}} \frac{1}{(2 \mathrm{n}+1)} \exp \left[-\frac{(2 \mathrm{n}+1)^{2} \pi^{2} \mathrm{D}_{\text {ef }} \mathrm{t}}{4 \mathrm{~L}^{2}}\right]
$$

Where $D_{\text {ef }}$ - effective diffusion coefficient $\left(\mathrm{m}^{2} \mathrm{~s}^{-1}\right), \mathrm{n}$ - number of terms in the equation ( $\mathrm{adm}$.), $\mathrm{L}$ - product thick (m).

The analytical solution of this equation is presented as an infinite series. Therefore, the finite number of terms (n) in truncation determines the accuracy of the results. This number was four $(n=4)$, since the effective diffusion coefficient did not change to higher values of (n).

Arrhenius' equation (Equation 13) was used to evaluate the temperature influence on effective diffusion coefficient (Doymaz; Tugrul; Pala, 2006; Gely; Giner, 2007; Gely; Santalla, 2007).

$$
\mathrm{D}_{\text {ef }}=\mathrm{D}_{0} \exp \left(-\frac{\mathrm{E}_{\mathrm{a}}}{\mathrm{RT}_{\mathrm{abs}}}\right)
$$

Where $\mathrm{D}_{0}$ - pre-exponential factor $\left(\mathrm{m}^{2} \mathrm{~s}^{-1}\right), \mathrm{E}_{\mathrm{a}}$ - activation energy $\left(\mathrm{kJ} \mathrm{mol}^{-1}\right), \mathrm{T}_{\mathrm{abs}}$ - absolute temperature $(\mathrm{K})$. 


\section{RESULTS AND DISCUSSION}

The drying curves of ginger slices (Figure 3) represent water loss of the product over drying time. The different drying periods are observed, constant rate period and decreasing rate, which according to Brooker, BakkerArkema and Hall (1992) occurs between moisture contents 2.33 to $3.00 \mathrm{~kg}_{\mathrm{a}} \mathrm{kg}_{\mathrm{dm}}{ }^{-1}$. To determine the mass and heat transfer coefficient and the modeling, we considered the critical moisture content of $2.33 \mathrm{~kg}_{\mathrm{a}} \mathrm{kg}_{\mathrm{dm}}{ }^{-1}$. According to Park et al. (2007), the amount of water available within the product in the constant rate period is very large. Water evaporates as free water, since its vapor pressure is constant and equal to the pure water vapor pressure at the temperature of the product. In turn, the temperature of the product is also constant and equal to the wet bulb temperature, because the mass and heat transfer transfers compensate.

Removing water inside the slices of ginger to the exposed surface is not sufficient to keep the product humidity. Thus, the period of decreasing drying rate conducted by the diffusion mechanism begins (Baptestini et al., 2015). In this period, according to Brooker, BakkerArkema and Hall (1992) heat transfer is not compensated by mass transfer because the internal resistance to water transport becomes greater than the external resistance.
Thus, water migration decreases from inside the product to its surface, and the temperature of the product increases, reaching the air temperature drying.

The overall heat transfer coefficient (Figure 4A) and mass (Figure 4B) increased with increasing drying temperature, ranging from 69.40 to $92.23 \mathrm{~W} \mathrm{~m}^{-2}{ }^{\circ} \mathrm{C}^{-1}$ and 0.062 to $0.089 \mathrm{~m} \mathrm{~s}^{-1}$, respectively. Values in this range were reported by Baptestini et al. (2017), Botelho et al. (2011) and Corrêa et al. (2009) working with infrared drying of banana slices, carrot slices and Fuji and Gala apple slices, respectively.

Bird, Stewart and Lightfoot (2004) state that the typical order of magnitude of heat transfer coefficient by convection is between 3.0 and $20.0 \mathrm{~W} \mathrm{~m}^{-2}{ }^{\circ} \mathrm{C}^{-1}$. The main reason for the higher values of such coefficient in this work is because drying is not only convective but a combination of radiation and convection (Corrêa et al., 2009). According to Incropera and Dewitt (2003) the coefficient depends on the condition of the limit layer, which is influenced by surface geometry, nature of fluid movement and various thermodynamic properties of fluid transport. Botelho et al. (2011) state that the coefficient of convective mass transfer defines the mass transfer rate without quantifying it, thus this coefficient is important to explain drying rates variation at different temperatures.

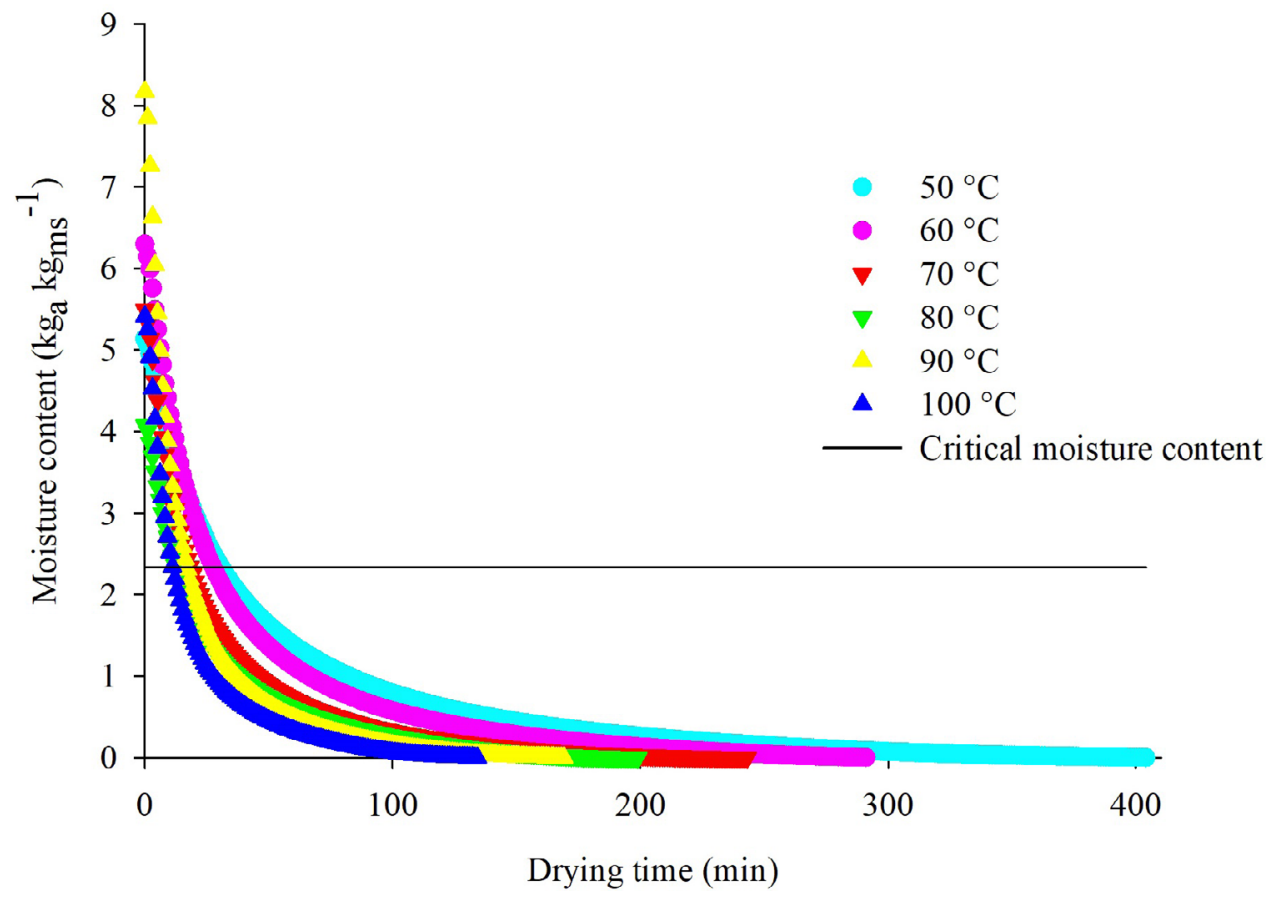

Figure 3: Ginger slice drying curves for $50,60,70,80,90$ and $100^{\circ} \mathrm{C}$. 

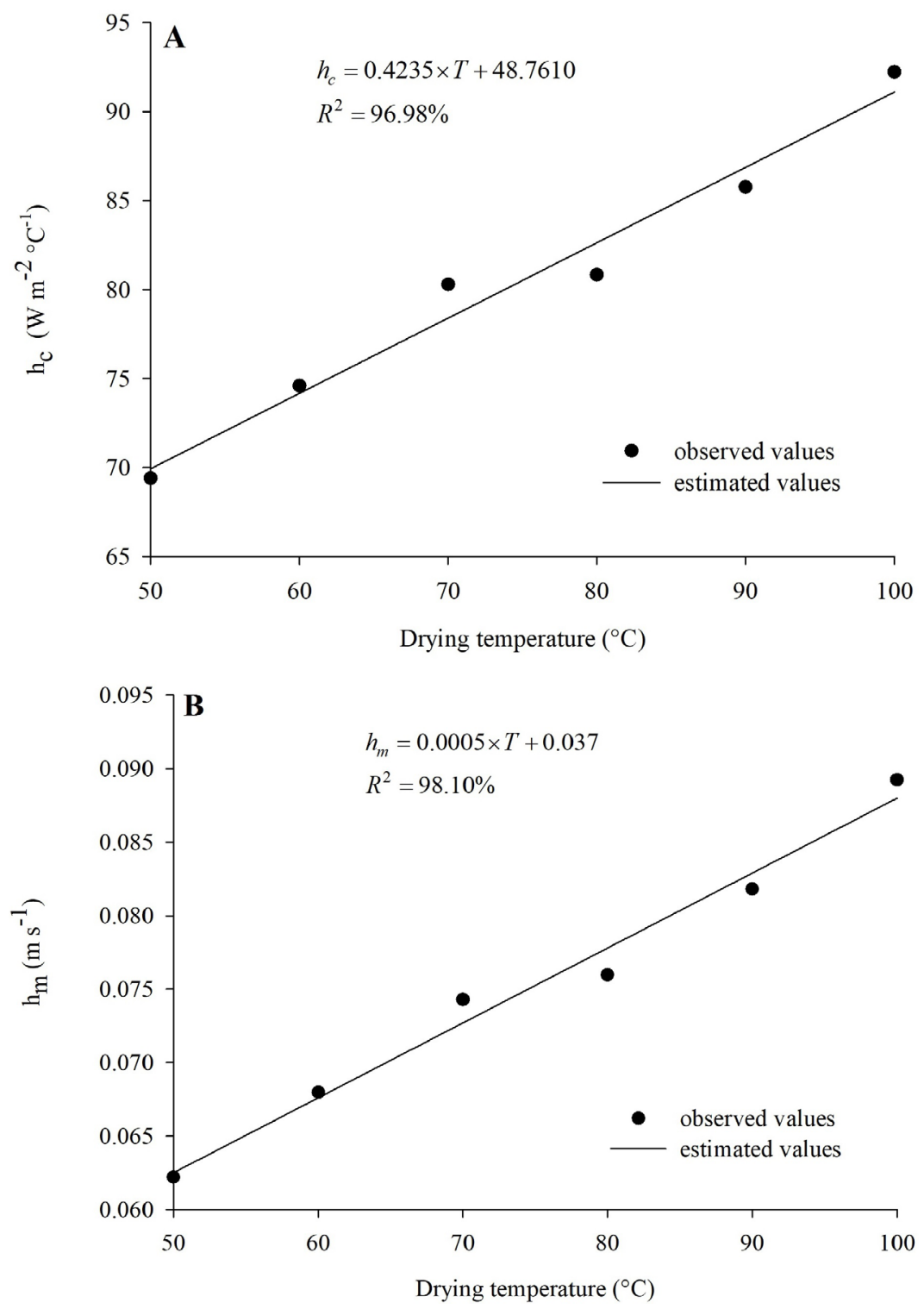

Figure 4: Global coefficient of transfer of heat (A) and mass (B) of ginger slices due to the drying temperature.

Lewis number (Le) values were $1.08 ; 1.10$; $1.13 ; 1.15 ; 1.17$ and 1.95 for the drying $50,60,70$, 80,90 and $100{ }^{\circ} \mathrm{C}$. This is a dimensionless number defined as the ratio of thermal diffusivity to mass diffusivity. It makes it possible to have an indication of which mechanism dominates the process. According to Hatami and Ganji (2014), if Le $>>1$, the process is limited by mass transfer; if $\mathrm{Le}<<1$, the process is limited by heat transfer; and if $\mathrm{Le}=1$, the processes are coupled. Thus, both processes conduct infrared drying of ginger slices.
According to the specialized literature, for a model to be adequate to describe a phenomenon, it has to show a value less than $10 \%$ relative mean error (Mohapatra; Rao, 2005), reduced value of estimated standard deviation (Draper; Smith, 1998), high coefficient of determination (Kashaninejad et al., 2007) and random residual distribution (Corrêa et al., 2014; Goneli et al., 2011; Resende et al., 2011). Thus, by analyzing Table 3 , only the modified Henderson and Pabis model meets all requirements simultaneously. 
Table 3: Relative mean error (MRE), estimated standard deviation (SDE), coefficient of determination $\left(\mathrm{R}^{2}\right)$ and residual distribution (RD) for the mathematical models used in the modeling of ginger slice drying.

\begin{tabular}{|c|c|c|c|c|c|c|c|c|}
\hline \multirow{2}{*}{ Model } & \multicolumn{4}{|c|}{$50^{\circ} \mathrm{C}$} & \multicolumn{4}{|c|}{$60^{\circ} \mathrm{C}$} \\
\hline & MRE (\%) & SDE & $\mathrm{R}^{2}(\%)$ & $\mathrm{RD}$ & MRE (\%) & SDE & $\mathrm{R}^{2}(\%)$ & $\mathrm{RD}$ \\
\hline (1) & 0.675 & 0.004 & 99.97 & $\mathrm{~B}$ & 0.866 & 0.005 & 99.95 & $B$ \\
\hline (2) & 22.311 & 0.019 & 99.20 & B & 28.983 & 0.022 & 99.20 & B \\
\hline (3) & 1.104 & 0.001 & 99.99 & $\mathrm{R}$ & 1.549 & 0.002 & 99.99 & $\mathrm{R}$ \\
\hline (4) & 16.957 & 0.018 & 99.33 & B & 21.983 & 0.019 & 99.19 & B \\
\hline (5) & 40.183 & 0.039 & 96.76 & B & 46.771 & 0.039 & 96.53 & B \\
\hline \multirow[t]{2}{*}{$(6)$} & 9.602 & 0.014 & 99.57 & B & 13.223 & 0.016 & 99.42 & B \\
\hline & \multicolumn{4}{|c|}{$70^{\circ} \mathrm{C}$} & \multicolumn{4}{|c|}{$80^{\circ} \mathrm{C}$} \\
\hline (1) & 1.979 & 0.006 & 99.93 & B & 3.066 & 0.008 & 99.88 & B \\
\hline$(2)$ & 25.095 & 0.020 & 99.13 & B & 16.594 & 0.019 & 99.33 & B \\
\hline (3) & 0.729 & 0.001 & 99.99 & $\mathrm{R}$ & 1.018 & 0.001 & 99.99 & $\mathrm{R}$ \\
\hline (4) & 19.114 & 0.018 & 99.35 & B & 14.760 & 0.018 & 99.41 & B \\
\hline (5) & 42.853 & 0.038 & 96.99 & B & 33.433 & 0.038 & 97.22 & B \\
\hline \multirow[t]{2}{*}{$(6)$} & 13.729 & 0.018 & 99.35 & $\mathrm{~B}$ & 9.615 & 0.018 & 99.38 & B \\
\hline & \multicolumn{4}{|c|}{$90^{\circ} \mathrm{C}$} & \multicolumn{4}{|c|}{$100^{\circ} \mathrm{C}$} \\
\hline (1) & 2.990 & 0.009 & 99.84 & B & 5.047 & 0.012 & 99.75 & B \\
\hline$(2)$ & 35.363 & 0.022 & 98.91 & B & 21222 & 0.021 & 99.20 & B \\
\hline (3) & 2.186 & 0.002 & 99.99 & $\mathrm{R}$ & 0.833 & 0.001 & 99.99 & $\mathrm{R}$ \\
\hline (4) & 29.199 & 0.020 & 99.18 & B & 19.057 & 0.018 & 99.41 & B \\
\hline (5) & 52.697 & 0.036 & 97.08 & B & 38.939 & 0.036 & 97.62 & B \\
\hline (6) & 22.040 & 0.021 & 99.05 & B & 16.037 & 0.023 & 99.06 & B \\
\hline
\end{tabular}

R: random; B: biased.

The curves of moisture dimensionless calculated and estimated by the Henderson and Pabis model, modified due to the drying time of ginger slices at different temperatures (Figure 5) confirm the good fit of the model. This satisfactorily explained all the drying. According to Oliveira et al. (2015) good correlation of the exponential part is expected, since the models mainly reflect this region of the graph. The error of the region tending to the equilibrium condition was minimized with the modeling up to $0.1364 \mathrm{~kg}_{\mathrm{a}} \mathrm{kg}_{\mathrm{dm}}{ }^{-1}$ (Brasil, 2005).

Table 4 shows the Henderson and Pabis equations modified with the inclusion of constants obtained in the modeling.

The effective diffusion coefficient increased with increasing drying temperature (Table 5). Temperature increase interferes with the physical properties of the fluids, contributing to an increase in the effective diffusion coefficient. According to Corrêa et al. (2009) two of them are more important for agricultural products: viscosity and molecular vibration of water and air molecules. The first directly relates to water transport in the porous capillary. The second decreases the vapor pressure of air and increases the vapor pressure in the product, leading to an increase in water concentration gradient, facilitating water removal. Some studies on infrared drying show several values of effective diffusion coefficient (Baptestini et al., 2017; Botelho et al., 2011; Corrêa et al., 2009; Corrêa et al., 2012), which according to Doymaz (2008) is in the range from $10^{-11}$ to $10^{-9} \mathrm{~m}^{2} \mathrm{~s}^{-1}$, as presented in this paper.

From Arrhenius representation (Figure 6), determining activation energy is possible. For ginger slices drying process, this was $22.07 \mathrm{~kJ} \mathrm{~mol}^{-1}$. Zogzas, Maroulis and Marinoskouris (1996) reported that the activation energy generally ranges from 12.7 to $110.0 \mathrm{~kJ} \mathrm{~mol}^{-1}$ for food; this study showed consistent value. 


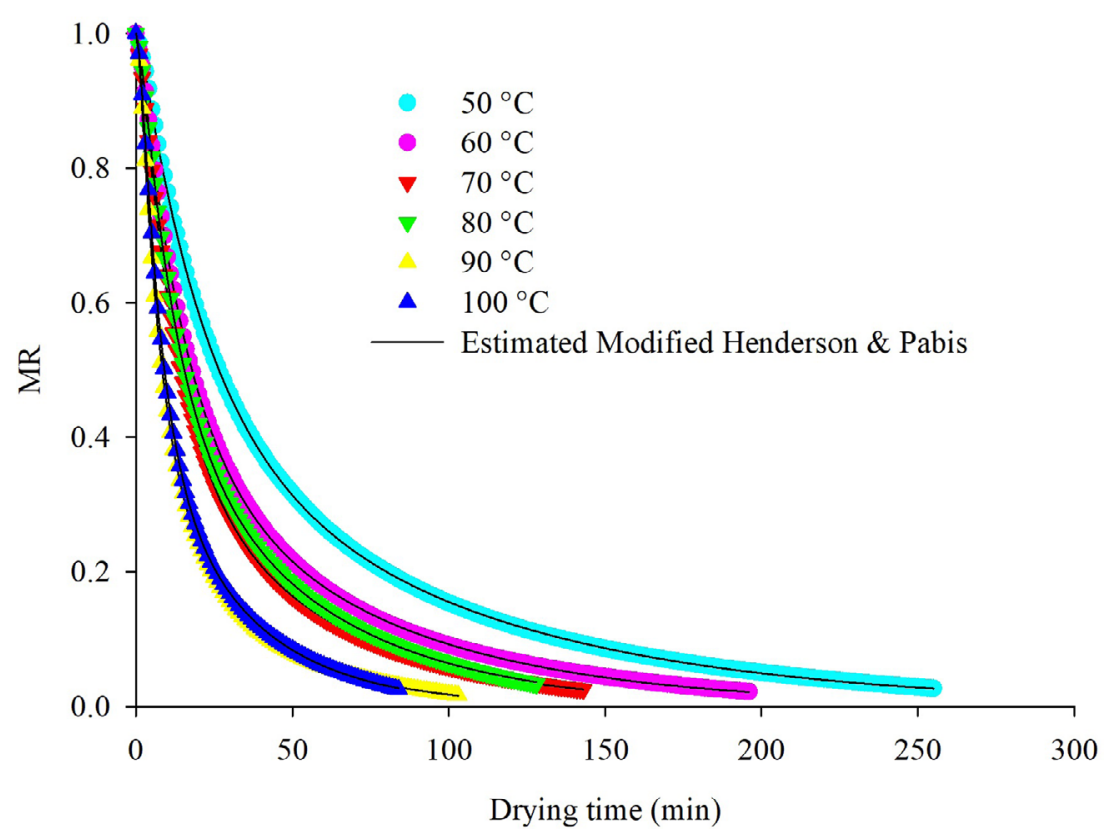

Figure 5: Moisture dimensionless calculated and estimated by the Henderson and Pabis model, modified due to the drying time.

Table 4: Henderson and Pabis model, modified to the experimental data of ginger slice drying.

\begin{tabular}{cc}
\hline Temperature $\left({ }^{\circ} \mathrm{C}\right)$ & Henderson and Pabis modified \\
\hline 50 & $\mathrm{MR}=0.572 \exp (-0.049 t)+0.463 \exp (-0.011 t)-0.037 \exp (-0.913 t)$ \\
60 & $\mathrm{MR}=0.627 \exp (-0.070 t)+0.420 \exp (-0.015 t)-0.048 \exp (-1.049 t)$ \\
70 & $\mathrm{MR}=0.651 \exp (-0.088 t)+0.415 \exp (-0.020 t)-0.068 \exp (-0.820 t)$ \\
80 & $\mathrm{MR}=0.601 \exp (-0.092 t)+0.487 \exp (-0.020 t)-0.088 \exp (-0.727 t)$ \\
90 & $\mathrm{MR}=0.365 \exp (-0.030 t)+0.739 \exp (-0.146 t)-0.104 \exp (-1.251 t)$ \\
100 & $\mathrm{MR}=0.438 \exp (-0.033 t)+0.737 \exp (-0.157 t)-0.174 \exp (-0.746 t)$ \\
\hline
\end{tabular}

Table 5: Effective diffusion coefficient of ginger slices at 50, 60, 70, 80, 90 and $100^{\circ} \mathrm{C}$.

\begin{tabular}{cc}
\hline Temperature $\left({ }^{\circ} \mathrm{C}\right)$ & Effective diffusion coefficient $\left(\mathrm{m}^{2} \mathrm{~s}^{-1}\right)$ \\
\hline 50 & $3.81 \times 10^{-9}$ \\
60 & $5.62 \times 10^{-9}$ \\
70 & $7.14 \times 10^{-9}$ \\
80 & $6.54 \times 10^{-9}$ \\
90 & $12.20 \times 10^{-9}$ \\
100 & $11.30 \times 10^{-9}$ \\
\hline
\end{tabular}




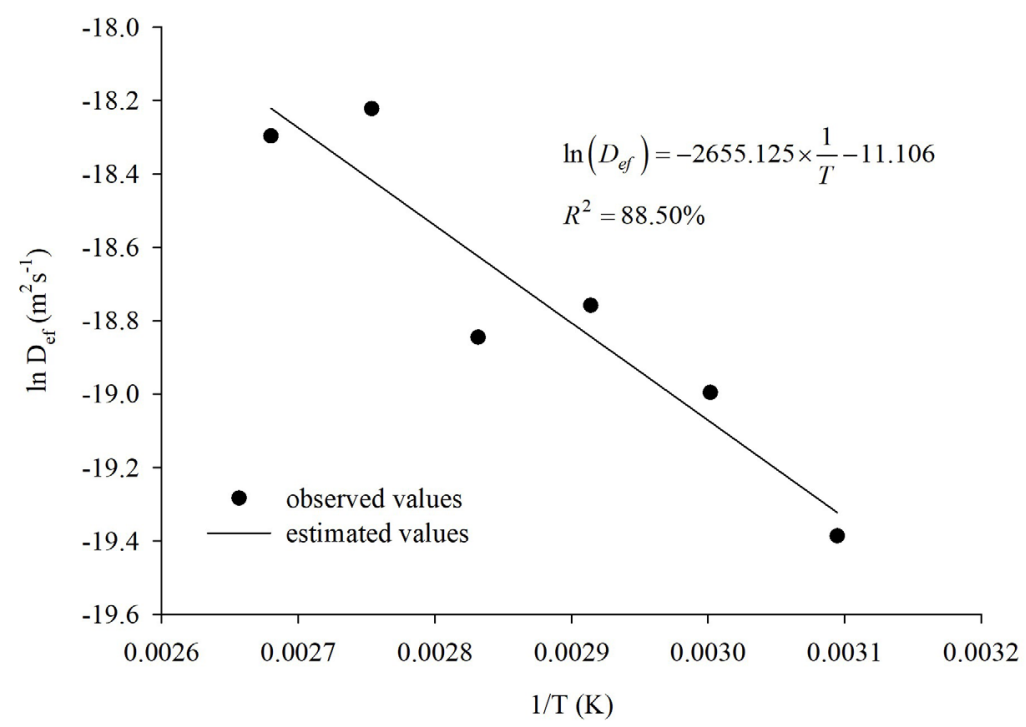

Figure 6: Arrhenius representation for effective diffusion coefficient of ginger slices at 50, 60, 70, 80, 90 and $100^{\circ} \mathrm{C}$.

\section{CONCLUSIONS}

The kinetics of infrared dehydration of ginger slices occurs simultaneously by heat transfer and mass transfer mechanisms. For the constant dehydration period, the heat and mass transfer coefficients varied respectively from 69.40 to $92.23 \mathrm{~W} \mathrm{~m}^{-2}{ }^{\circ} \mathrm{C}^{-1}$ and from 0.062 to 0.089 $\mathrm{m} \mathrm{s}^{-1}$. These coefficients variation with temperature was described by a linear model. For the decreasing dehydration period, the modified Henderson and Pabis model best described the kinetics of ginger slice drying, with effective diffusion coefficient ranging from $3.81 \times 10^{-9}$ to $1.13 \times 10^{-8} \mathrm{~m}^{2} \mathrm{~s}^{-1}$ and activation energy of $22.07 \mathrm{~kJ} \mathrm{~mol}^{-1}$.

\section{REFERENCES}

ADAK, N.; HEYBELI, N.; ERTEKIN, C. Infrared drying of strawberry. Food Chemistry, 219(3):109-116, 2017.

AFZAL, T. M.; ABE.; T. Diffusion in potato during far infrared radiation drying. Journal of Food Engineering, 37(6):353365, 1998.

AFOLABI, T.; TUNDE-AKINTUDE, T.; OYELADE, O. Influence of drying conditions on the effective moisture diffusivity and energy requirements of ginger slices. Journal of Food Research, 3(5):103-112, 2014.

AN, K. et al. Comparison of different drying methods on Chinese ginger (Zingiber officinale Roscoe): Changes in volatiles, chemical profile, antioxidant properties, and microstructure. Food Chemistry, 197(4):1292-1300, 2016.

ARABLOU, T.; ARYAEIAN, N. The effect of ginger (Zingiber officinale) as an ancient medicinal plant on improving blood lipids. Journal of Herbal Medicine, 10(6):1-9, 2017.

BAPTESTINI, F. M. et al. Modelagem matemática da secagem de espuma de graviola. Revista Brasileira de Engenharia Agrícola e Ambiental, 19(12):1203-1208, 2015.

BAPTESTINI, F. M. et al. Constant and decreasing periods of pineapple slices dried by infrared. Revista Brasileira de Ciências Agrárias, 11(1):53-59, 2016.

BAPTESTINI, F. M. et al. Heat and mass transfer coefficients and modeling of infrared drying of banana slices. Revista Ceres, 64(5):457-464, 2017.

BIRD, R. B.; STEWART, W. E.; LIGHTFOOT, E. N. Fenômenos de Transporte. 2.ed. Rio de Janeiro: LTC, 2004. 838p.

BOTELHO, F. M. et al. Periods of constant and falling-rate for infrared drying of carrot slices. Revista Brasileira de Engenharia Agrícola e Ambiental, 15(8):845-852, 2011.

BRASIL. Agência Nacional de Vigilância Sanitária. Resolução da Diretoria Colegiada - RDC n. 272, de 22 de setembro de 2005. Regulamento Técnico para produtos de vegetais, produtos de frutas e cogumelos comestíveis, Diário Oficial da União, Brasília, DF, Brasil, 2005. p. 1-6. 
BROOKER, D. B.; BAKKER-ARKEMA, F. W.; HALL, C. W. Drying and storage of grains and oilseeds. Connecticut: The AVI Publishing Company, 1992. 450p.

CORRÊA P. C. et al. Determinação dos coeficientes de transferência de calor e de massa da desidratação por infravermelho de fatias de maçã Fuji e Gala. In: DI LEO, N.; MONTICO, S.; NARDÓN, G. Avances en Ingeniería Rural. Santa Fé: UNR Editora, 2009. p.1060-1066.

CORRÊA, P. C. et al. Tomato infrared drying modeling and some coefficients of the dehydration process. Chilean Journal of Agricultural Research, 72(2):262-267, 2012.

CORRÊA, P. C. et al. Isotermas de sorção de água de frutos de Coffea canephora. Revista Brasileira de Engenharia Agrícola e Ambiental, 18(10):1047-1052, 2014.

DEHGHANNYA, J.; HOSSEINLAR, S. H.; HESHMATI, M. K. Multistage continuous and intermittent microwave drying of quince fruit coupled with osmotic dehydration and low temperature hot air drying. Innovative Food Science \& Emerging Technologies, 45(2):132-151, 2018

DESHMUKH, A. W. et al. Investigation of solar drying of ginger (Zingiber officinale): Empirical modelling, drying characteristics, and quality study. Chinese Journal of Engineering, 14(3):1-7, 2014.

DOYMAZ, I. Convective drying kinetics of strawberry. Chemical Engineering and Processing, 47(5):914-919, 2008.

DOYMAZ, I.; TUGRUL, N.; PALA, M. Drying characteristics of dill and parsley leaves. Journal of Food Engineering, 77(3):559-565, 2006.

DRAPER, N. R.; SMITH, H. Applied regression analysis. 3.ed. New Jersey: John Wiley \& Sons, 1998. 712p.

GARB, S. A.; ALGHADIR, A. H.; GHONIEM, G. A. Biological activities of ginger against cadmium-induced renal toxicity. Saudi Journal of Biological Sciences, 24(8):1-7, 2017.

GEHAKA - Manual Medidor de Umidade por Infravermelho IV 2500. Available in: http://www.gehaka.com.br/ sistema/produtos/278/m_iv2500.pdf. 2011. Access in: 18 dec 2018.

GELY, M. C.; GINER, S. A. Diffusion coefficient relationships during drying of soya bean cultivars. Biosystems Engineering, 96(2):213-222, 2007.

GELY, M. C.; SANTALLA, E. M. Moisture diffusivity in quinoa (Chenopodium quinoa Willd.) seeds: Effect of air temperature and initial moisture content of seeds. Journal of Food Engineering, 78(3):1029-1033, 2007.
GONELI, A. L. D. et al. Contração volumétrica e forma dos frutos de mamona durante a secagem. Acta Scientiarum Agronomy, 33(1):1-8, 2011.

HATAMI, M.; GANJI, D. D. Investigation of refrigeration efficiency for fully wet circular porous fins with variable sections by combined heat and mass transfer analysis. International Journal of Refrigeration, 40(4):140-151, 2014.

INCROPERA, F. P.; DEWITT, D. P. Fundamentos de Transferência de Calor e Massa. 5.ed. Rio de Janeiro: LTC, 2003. 698p.

JAYASHREE, E.; VISVANTHAN, R. Studies on thin layer drying characteristics of ginger (Zingiber officinale) in a mechanical tray drier journal of plantation crops. Journal of Plantation Crops, 41(1):86-90, 2013.

JELLED, A. et al. Chemical and antioxidant parameters of dried forms of ginger rhizomes. Industrial Crops and Products, 77(12):30-35, 2015.

KASHANINEJAD, M. et al. Thin-layer drying characteristics and modeling of pistachio nuts. Journal of Food Engineering, 78(1):98-108, 2007.

KATE, A.E.; SUTAR, P.P. Development and optimization of novel infrared dry peeling method for ginger (Zingiber officinale Roscoe) rhizome. Innovative Food Science \& Emerging Technologies, 48(8):111-121, 2018.

MOHAPATRA, D.; RAO, P. S. A thin layer-drying model of parboiled wheat. Journal of Food Engineering, 66(4):513518, 2005.

NOWAK, D.; LEWICKI, P. Infrared drying of apple slices. Innovative Food Science \& Emerging Technologies, 5(3):353-360, 2004.

OLIVEIRA, G. H. H. et al. Modelagem e propriedades termodinâmicas na secagem de morangos. Brazilian Journal Food Technology, 18(4):314-321, 2015.

OZDEMIR, M. B. et al. Modeling of a convective-infrared kiwifruit drying process. International Journal of Hydrogen Energy, 42(28):18005-18013, 2017.

PATTNAIK, P.K. et al. Molecular \& Biochemical characterization of selected elite accessions of ginger. Biocatalysis and Agricultural Biotechnology, 8(10):130-138, 2016.

PARLAK, N. Fluidized bed drying characteristics and modeling of ginger (Zingiber officinale) slices. Heat Mass Transfer, 51(8):1085-1095, 2015.

PARK, K. J. et al. Conceitos de processos e equipamentos de secagem. Campinas: Editora UNICAMP, 2007. 121p. 
PHOUNGCHANDANG, S.; SAENTAWEESUK, S. Effect of two stage, tray and heat pump assisted-dehumidified drying on drying characteristics and qualities of dried ginger. Food and Bioproducts Processing, 89(4):429437, 2011.

PINELA, J. et al. Influence of the drying method in the antioxidant potential and chemical composition of four shrubby flowering plants from the tribe Genisteae (Fabaceae). Food and Chemical Toxicology, 49(11):2983-2989, 2011.

RAHMANI, A. H.; SHABRMI, F. M.; ALYM S. M. Active ingredients of ginger as potential candidates in the prevention and treatment of diseases via modulation of biological activities. International Journal of Physiology, Pathophysiology and Pharmacology, 6(2):125-136, 2014.

RESENDE, O. et al. Modelagem matemática e difusividade efetiva das sementes de pinhão-manso Vatropha curcas
L.) durante a secagem. Engenharia Agrícola, 31(6):11231135, 2011.

STATSOFT, INC. Programa computacional Statistica 7.0. E.A.U. 2004.

TOGRUL, H. Suitable drying model for infrared drying of carrot. Journal of Food Engineering, 77(3):610-619, 2006.

YOUNIS, M.; ABDELKARIM, D.; EL-ABDEIN, A. Z. Kinetics and mathematical modeling of infrared thin-layer drying of garlic slices. Saudi Journal of Biological Sciences, 25(2):332-338, 2018.

YU, W. M. D. et al. Evaluation of daily ginger consumption for the prevention of chronic diseases in adults: A cross-sectional study. Nutrition, 36(4):79-84, 2017.

ZOGZAS, N. P.; MAROULIS, Z. B.; MARINOSKOURIS, D. Moisture diffusivity data compilation in foodstuffs. Drying Technology, 14(5):2225-2253, 1996. 